occupy the same volume." From experiments on friction of gases, velocity of gaseous diffusion, \&c., conclusions have been drawn as to the size; of different molecules; Avogadro's law, however, says nothing as to the relative dimensions of molecules : the conclusion drawn by the author from Avogadro's law is therefore 1 think rightly called an "erroneous" conclusion, apart from any considerations as to the accuracy of the statement, "the molecules of all gases are of the same size."

A knowledge of the "atomicity" of the most important elements would, I admit, be of much importance. But when the evidence on which this or that value is assigned to the "atomicity" of these elements is examined, it is found in most cases to be very slight : a great structure has been raised on a shifting foundation. A student who has conmitted to memory the assertion that the "atomicity" of the nitrogen atom is five is probably ready to receive with gratitude the formula for nitrous oxide referred to; had he asked for the evidence on which the assertion as to the atomicity of nitrogen rests, and for an explanation of the assertion itself, he would I think hesitate before accepting the graphic formula in question as in any way affurding "accurate and well-grounded information."-THE WRITER OF THE NOTICE.]

\section{The Recent Weather}

REFERRING to the leading article on "The Recent Weather" in a former number, perhaps the following proverb, prevailing $I$ think in Norfolk, may possess some interest:-

$$
\begin{aligned}
& \text { "When Martinmas ice will bear a duck, } \\
& \text { The winter will all be mire and muck." }
\end{aligned}
$$

Martinmas Day is on November I I. Bearing in mind that Martinmas, like Christmas, connotes a season rather than a particular day, and still more, that cold weather would usually come earlier in Scotland than in the eastern counties, the proverb seems to be entirely in unison with Sir Robeit Christison's prognostic.

Toppesfield Rectory, Halstead, Essex

Father Lobo's "Abyssinia."-A correspondent asks if there is any trustworthy evidence that Lobo's " History of Abyssinia" was ever published in Portuguese, as stated in most biographies. The extracts translated by Sir Peter Wyche and published by the Royal Society in the end of the seventeenth century, were made from the manuscripts, as was also Legrand's translation in the beginning of the eighteenth, from which Dr. Johnson made his epitome. In Burbosa-Machado's "Bibliotheca Lusitana" there is no mention of a Portuguese edition.

\section{ON THE WHALE FISHERYOF THE BASQUE} PROVINCES OF SPAIN ${ }^{1}$

$M Y$ attention was drawn to the Basque Whale-Fishery My observing, during my study of Arctic literature, and especially while editing the voyages of William Baffin, that the first English whaling vesiels were in the habit of shipping a boat's crew of Basques to harpoon the whales. I was informed that a whale, the Balana biscayensis, had frequented the coasts of the Basques provinces from time immemorial; but that it had become nearly extinct in the seventeenth century, when the Basques began to extend their voyages further $n \jmath r t h$, and across the Arctic Circle. Hence the Basques had become dexterous whale-fishers long before any other European people had entered upon that perilous occupation.

I found that several naturalists had investigated the history of the Biscayan whale, notably Eschricht and Reinhardt in Denmark, M. Fischer in France, and Prof. Flower in this country. Full information respecting these investigations is contained in E; chricht and Rei.lhardt's memoir, published by the Ray Society in 1866: and many interesting particulars have since been brought to light respecting the whale-fishery so far as it relates to the French Basques, and to the ports of Bayonne, Biarritz, Guétary, St. Jean de Luz, and Ciboure. But in looking th:ough the books and papers on the subject, a list of which was kindly

I By Clements R. Markham. C. B., F.R.S. Read at the Zool ugical Society, I. By Clements R. Markham, C.B., F. R.S
December I3. Revised by the Author. furnished to me by Prof. Flower last June, I did not find any particulars respecting the Spanish ports, where the Basque sailors are more numerous than in France, and inhabit a more extensive line of coast. I therefore thought it possible that, by visiting those ports and making inquiries respecting the literature of the provinces in which they are situated, and the local traditions, I might be able to collect some further information touching the whalefishery of the Basques. It has now been suggested to me that such particulars as I have succeeded in bringing together, from their bearing on the history of the Baliena biscayensis, a nearly extinct animal, would be interesting to the Zoological Society. I thercfore have pleasure in communicating the following notes on the subject.

The coast which I personally visited this summer extends from the French frontier to the :Cabo de Peñas, including the Basque provinces of Guipuzcoa and Vizcaya, and the purely Spanish provinces of Santander and the Asturias. It is for the most part bold and rocky, with lofty cliffs of cretaceous limestone, having strata hove up at great angles. Occasionally there is a stretch of sand, generally at the mouths of rivers, and here and there a rocky little boat-harbour. Forests of oak and chestnut clothe the mountains, with occasionally open spaces of fern and heather and bushes of arbutus and myrtle. In some places the chestnut-groves come down almost to the water's edge. Along this coast there are many small fishing-towns. Fuenterrabia, on its picturesque hill, overlooks the French frontier. Following the coast to the westward the next port is Pasajés, and then comes the city of San Sebastian, which was the centre of the old whale-fishery. Zarauz is a town stretching along the shores of a sandy bay. Guetaria is built in a cleft of rocks which are sheltered behind the island of San Anton. Zumaya and Deva are are at the mouths of rivers; and Motrico is a picturesque little town built on steep slopes like Clovelly, overlooking a rocky bay. These are the ports of Guipuzcoa.

Ondarroa, at the mouth of its river, where small schooners are still built, is the first port of Vizcaya, coming from the east. Lequeitio is a large and more important place, sending out ábout a hundred fishing-boats. Next come Mundaca, at the mouth of the river of Guernica, Bermeo, another populous fishing-town with as many, boats as Lequeitio, Plencia, and Portugalete and Santurce in the bay of Bilbao. These are the principal Vizcayan ports. The province of Santander has Castro-Urdiales, Laredo and Santoña on the shores of a large harbour, Santander itself, and San Vicente de la Barquera. In the Asturias are the ancient ports of Llanes, Rivadesella, Villaviciosa, the important town of Gijon, Candas, and Luanco. From the little village of Luanco to the end of the Cabo de las Peñas is a walk of eight miles, and this was the most western point I reached.

The Basque fishermen are a handsome race. They go away on their fishing-voyages for many days, and are brave honest, and industrious; while both men and women are always cheerful and light-hearted. They belong to a people who, for centuries, have repelled foreign invasion, have enjoyed free institutions, and made their own laws. The Basque fishermen are the descendants of the old whalers, and retain their traditions. They have, from time to time, produced naval worthies whose names are historical. Among them are Sebastian del Cano, a native of the little fishing-town of Guetaria, who was the first circumnavigator of the globe; Legaspi, the conqueror of the Philippine Islands ; Machin de Munguia, the Spanish Grenville; and Churruca, whose gallantry at the battle of Trafalgar won for him the admiration of his English foes.

Such men were the product of the whale-fishery, which was for the Basques, as it has since been for the British, an admirable nursery for seamen.

My first inquiries had reference to the antiquity of the 
Basque whale-fishery. The following facts show that it was a well established trade in the twelfth century, so that it probably existed at least two centuries earlier. King Sancho (the Wise) of Navarre granted privileges to the city of San Scbastian in the year II50 A.D. In this grant there is a list of articles of merchandise with the duties that must be paid for warehousing them : whale-bone has a prominent place in the list. "Carga de boquinas-barbas de ballenas . ...2 dineros." The same privileges were extended by Alfonso VIII. of Castille to Fuenterrabia in 1203 , and to Motrico and Guetaria in $\mathrm{I}_{204}$. Ferdinand III., in a royal order dated at Burgos the 28th September, I237, gave similar privileges to Zarauz; and this document contains further proof of the antiquity of the whale-fishery. For a claim is made that, in accordance with custom ("sicut forum est") the King should have a slice of each whale, along the backbone, from the head to the tail. The custom here referred to indicates the antiquity of the fishery. At Guetaria it was the custom to give the first fish of the season to the King, who usually returned half.

Another proof of the importance of the whale-fishery on the northern coast of Spain, and probably also of its antiquity, is the fact that no less than six of the towns have a whale for their coat of arms. This charge is in the arms of Fuenterrabia. Over the portal of the first house in a steep uld street of Guetaria there is a shield of arms consisting of a whale amidst waves of the sea. At Motrico the town arms consist of a whale in the sea, harpooned, and a boat with men holding the line. The same device is carved on the wall of the Town Hall of Lequeitio. The arms of Bermeo and Castro-Urdiales also contain a whale. I was assured that vigias or look-out posts were established on the headiands, and high up the mountains overlooking the fishing-towns, whence notice was given directly a whale was seen spouting in the offing; and soon the boats were in pnrsuit. On the mountain of Talaya-mendi ("Look-out mountain") above Zarauz, there are some ruined walls which, according to Madoz, are the remains of one of these watch-towers, whence warnings were sent down the moment a whale was in sight. In some of the towns there are records which throw light on the whale-fishery, but (chiefly during the French occupation) most of the ancient archives have been destrojed or are lost. Fortunately this is not universally the case. In the town of Lequeitio eight of the "libros de fabrica" or fabric rolls of the church, commencing from the year I 510 , have been preserved, which contain much interesting information.

The most ancient document relating to whales in the Lequeitio archives is dated September IIth, I38I. It is there ordered and agreed by the Cabildo that the whalebone taken shall be divided into three parts, two for repairing the boat-harbour, and the third for the fabric of the church. The same order is repeated in another document dated $\mathrm{I} 608$. In the Libros de fabrica de la iglesia de Lequeitio there is a list of the whale killed, in various years, by the boats of Lequeitio, from I 5 I 7 to $166 \mathrm{I}$.

1517. Two whales killed. 1525. Returns in money value. I531. January and February, two large and one small whale killed, 1532. None killed. I 536. Two large whales and one small. I 538. Six whales killed. I 542. Two whales killed. I 543. One whale wounded by the Lequeitio people, but captured at Motrico. Divided between the two towns. 1543. Two whales killed, mother and young. The Mayor-domo working all day at the whalebone, and received 2 rials. 1546. February 24 , a whale killed in front of St. Nicholas Island. The bone yielded $9 \frac{1}{2}$ ducados. I550. Two whales killed. 1570. One whale killed. 1576. One whale killed. I578. One whale killed. 1580. Three and a young one. 1608. One whale killed. I609. Three whales killed. 16II. Two small whales killed, in concert with the men of Andarroa, which led to a law-suit. 1617. One whale killed. 1618. One whale killed. 1619. One whale killed. 1622. One whale killed with its young. 1649. Two whales killed. 1650. Two whales killed. I657. Two whales killed and two young. 166r. One whale killed.

In the Libro de Fabrica including the years from I73I to $178 \mathrm{I}$ there is no mention of a whale, nor in the two succeeding books. The sailors went long voyages in search of them. But in 1712, fifty years after the last entry in the books, there were boats and apparatus for catching whales. In I740 it was said that there were no sailors in Lequeitio, all having gone on long whaling voyages. In a record of a marriage at Lequeitio on July

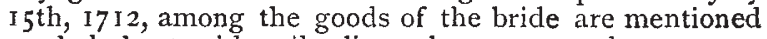
a whale-boat with sails, lines, harpoons, and apparatus complete. Of the bridegroom it is said that "he was clothed decently, having four coats of London cloth, a good chest to keep his clothes in and another for travelling, a mattras, pillow, and blanket, and needful clothes for going to sea." So that between them they were well prepared for a whaling expedition.

These entries at Lequeitio indicate that, during the sixteenth century, the whales were abundant; for if this was the catch of only one village out of at least twenty along the coast, we may fairly multiply it by at least ten for the average yield of the fishery.

In the books of the Cofradia de Mareantes of Zarauz there are similar records, from which it appears that between the years 1637 and. I8OI as many as fifty-five whales were killed by the Zarauz people, whose prowess was known throughout the Cantabrian coast. There is one noteworthy tradition at Zarauz, to the effect that two young sailors, without any help, chased, harpooned, and killed a large whale, and brought it safely to the beach. This deed is immortalised on imperishable stone. Over the portal of a house in Zarauz, No. 13 Calle de Azara, there is an inscription, now in the greater part rendered illegible by time, but with letters of the shape and styla used in the sixteenth century. To the left of the inscription there is carved a harpooned whale, with the line fastened to a boat, in which are two men. Don Nicolas de Soraluce, the learned historian of Guipuzcoa, told me that an old resident in Zarauz, named Belaunzarán, had often spoken to him of the feat recorded on this stone slab ; adding that he used to hear his grandmother explain that the carving represented the harpooning and killing of a whale by two young sailors in a single boat. This deed was considered worthy of being handed down to posterity, and the stone was therefore placed over the door of the house of these two brothers, or, as some say, a father and son.

There are some other records as to the disposition of the whalebone. By an order dated November 2oth, I474, the town of Guetaria gave half the value of each whale towards the repair of the church and of the boat-harbour. In San Sebastian, according to an ancient custom, the whalebone was given to the Cofradia (brotherhood) of San Pedro.

It is clear that the whales, close along the coast, became very scarce in the middle of the seventeenth century, when the entries at Lequeitio cease, and that the Basque sailors then began to seek the means of exercising their special craft by making long voyages, even to the Arctic regions. Such voyages were occasionally made at a still earlier period. It is stated by Madoz that a pilot of Zarauz, named Matias de Echeveste, was the first Spaniard who visited the banks of Newfoundland; and, according to a memoir written by his son, that he made twenty-eight voyages from I 545 to 1599 , Ihe year of his death. In the accounts of the first English whaling voyages to Spitzbergen, in the collection of Purchas, we read of Basque ships from San Sebastian frequenting those Arctic seas in search of whales, and of the overbearing way in which their captains were often treated by the English. Nevertheless, the English were glad to 
obtain the help of the Basque sailors to do for them the most perilous and difficult part of the work, namely, the harpooning and killing of the whales.

I gather from Eschricht and Reinhardt's memoir, that this Biscayan whale was known to the French Basques as the Sarde, and was the same as the Nordkaper of the Dutch and North Germans, and the Sletbag of Iceland, a whalebone whale. but smaller and more active than the great Greenland whale. The Konge-speil (an ancient Norwegian record) has a passage to the effect that "those who travel on the sea fear it much, for its nature is to play much with vessels." Belonging to the temperate North Atlantic, it is described as much more active than the Greenland whale, much quicker and more violent in its movements, more difficult and dangerous to catch. It is smaller and has less blubber than the Mysticetus, the head shorter, and the whalebone much thicker, but scarcely more than half as long.

For centuries the Basques had attacked and captured this formidable Cetacean ; and they, in fact, monopolised all the experience and skill which then existed in connection with the craft and mystery of whale-fishing. To the sailors of all other nations it was an unknown business, appearing all the more perilous from their absence of knowledge. So it was natural that the hardy and intrepid fishermen from the Cantabrian coast should be in requisition as harpooneers, as soon as the English and Dutch entered upon the Arctic whale-fishery, early in the seventeenth century. With their services, we also borrowed their words. Harpoon is derived from the Basque word Arpoi, the root being ar, "to take quickly." The Basque Harpoinari is a "harpooneer."

There is a letter still extant at Alcala de Henares, from James I. of England to the king of Spain, dated $16 \mathrm{I}_{2}$, in which permission is asked to engage the services, on board English ressels engaged in the Arctic whaling-trade, of Basque sailors skilled in the use of the harpoon. The fact that Basque boats' crews were frequently shipped seems to show that this request was granted. In the whaling fleet fitted out for Spitzbergen in 1613 , under the command of Benjamin Joseph, with Baffin on board the general's ship as pilot, twenty-four Basques were shipped. Orders were given that "they were to be used very kindly and friendly, being strangers and leaving their own country to do us service." The English seem to have adopted the fishing rules of the Basques, as well as to have benefited by their skill and prowess. Thus we read of an order being given because "the order of the Biscaines is that whoso doth strike the first harping-iron into him, it is his whale, if his iron hold." The Basques went out to attack the whales in the offing, while the English got ready for boiling-down. We read:- "News was brought to us this morning that the Basks had killed a whale; therefore we hasted to set up our furnaces and coppers, and presently began work; which we continued, without any want of whales, till our voyage was made "-thanks to the Basques. In another place Baffin calls the Basques "our whale strikers." Of course the English, in due time, learnt to strike the whales themselves; but the Basques were their instructors; and it is therefore to this noble race that we owe the foundation of our whaling trade.

In travelling along the coast, I found a universal tradition of the whale-fishery; and often the families of fishermen had the harpoons hanging in their houses, which had been there for generations. They still have occasion to use them when porpoises come within range ; and on board one of the Gijon steamers there was a man with unerring aim. But many harpoons hang on the walls as relics of the old whaling days. At Laredo the fishermen brought me a harpoon of peculiar construction. The point was narrow and very slightly barbed, but there was a hinge half-way up the point, which was kept in line with the shaft by a ring. When the harpoon entered a whale, the ring slipped, the hinge turned, and the point came at right angles to the shaft, making it impossible for the harpoon to come out again. Baron Nordenskiöld informs me that this kind of harpoon is used by the Norwegians to kill the white whales.

At Llanes, in Asturias, I found a large palatial house which was formerly the "Casa de Ballenas," or house where business connected with the whale fishery was transacted. At Gijon there is also a "Casa de Ballenas," and also a street called Whale-lane. These names, with the coats of arms and traditions, are all relics of the old whaling days. At San Sebastian, too, there are enormous tinajas, or earthenware jars, in which the oil was stored.

It was at one time supposed that the Balana biscayensis had become quite extinct; but this is certainly not the case. Whales are seen on the Cantabrian coast at intervals of about ten years. In 1844 a whale was seen off Zarauz. Boats went out and it was hit, but it broke the lines, and got away with two harpoons and three lances in its body, after having towed the boats for six hours. On the 25 th of July, I850, early in the morning, a whale appeared off Guetaria. Boats quickly pursued it, but the harpooneer missed his aim, and the whale went off, heading N.W. In January I 854 a whale and her two young entered the bay of San Sebastian. One of the young whales was singled out for attack, but the mother made desperate efforts to defend it, and once broke the line. Eventually the mother and one calf escaped, while the other was secured. Of course, with proper boats and apparatus, and if the fishermen had had a little of their ancestors' experience, all three would have been caught. It is the skeleton of this young whale that Professor Eschricht purchased at Pampluna. It is now at Copenhagen.

While I was at Gijon, in the Asturias, I was told by an old fisherman that a whale had been caught, about twenty years ago, by the villagers near the lighthouse on Punta de Peñas. The story was not believed by merchants and others of whom I made inquiries, so I thought it best to investigate the matter myself. I, therefore, went westward to the little fishing-village of Luanco, and next day proceeded on foot across a wild mountainous country to the lighthouse of Punta de Peñas; a distance of sixteen miles there and back. There, in the court-yard of the lighthouse, was a whale's jaw-bone, and the man in charge corroborated the story. But he added the curious statement that the whale was dead and half flensed, drifting in under the land, when the villagers first saw it, and went out in their boats to tow it on shore. I also found parts of the rib-bones in the granary of a farm-house at Viodo, a hamlet near the lighthouse.

The last whale of which I obtained intelligence was sighted between Guetaria and Zarauz on the IIth of February, 1878. Many boats went out from these two places, and one boat from Orio. The first harpoon that kept fast was thrown by a smart young sailor of Guetaria, the countryman of Sebastian del Cano, the first circumnavigator of the globe. He is $n d w$ in the Spanish navy. Eventually the whale was killed and towed on shore. No one derived any benefit, because there was a law-suit tried at Azpeitia. It appears that the harpoon was of Guetaria, but that the line belonged to Zarauz. Meanwhile the whale became unpleasant and had to be blown up. The authorities of San Sebastian, however, through the intervention of Don Nicolas Soraluce, secured the bones, and the skeleton is now carefully set up in the small museum in that city. It is 48 feet long, and part of the whale-bone remains in the jaw. There are also bones of a whale found in the sands at Deva in the same museum. I was given part of a whale's rib dug up on the Lequeitio beach, and a jaw-bone which was long in the court-yard of the palace of the Count of Revillagigedo at Gijon, is now preserved in the Jovellanos Institute, in the same town. Of course there must be any number of 
bones buried in the sand of the beaches where so many hundreds of whales have been flensed in former centuries.

In 1878 the accomplished historian of Guipuzcoa, Don Nicolas Soraluce, printed a pamphlet at Vitoria on "the origin and history of the whale and cod fisheries," which contains much interesting information. I may add that Señor Soraluce is preparing some additional chapters on the whale-fishery, and that be expects to obtain copies of interesting documents relating to the same subject from the archives of the Ministry of Marine at Madrid.

\section{A SYSTEM OF METEOROLOGICAL OBSER- VATIONS IN THE CHINA SEAS}

$\mathrm{T}$ a recent article in NATURE we referred to the proposal to establish an observatory at Hongkong under the superintendence of Major Palmer, R.E., and expressed a hope that Mr. Hart, of the Chinese Maritime Customs, would be successful in his efforts for the establishment of a number of meteorological stations along the coast of China. The China seas, on account of their numerous currents and destructive typhoons, are especially dangerous to shipping, and the value, in a material sense, of a thorough and accurate series of observations of this kind can hardly be overrated. Moved by these considerations, the Shanghai General Chamber of Commerce, the most numerous and influential foreign mercantile body in the Far East, has taken the matter in band, and at a recent meeting, reported in the Celestial Empire, discussed "the feasibility of organising a system of meteorological reports from the China coast and the interior, with the view of improving the knowledge of the origin and direction of storms, and warning mariners of their approach." The Chamber wisely consulted the Reverend Father Dechevrens, director of the Jesuits' Observatory at Siccawei, not far from Shanghai, who recommended that the object of the system should be twofold :-(I) To give shipmasters a sufficient knowledge of the meteorology of Chinese and Japanese waters to enable them at all times, and especially at critical moments, to recognise the best routes to follow in order to reach their destinations as speedily as possible, and emerge with credit from storms which they have been unable to avoid; and (2) to give vessels about to leave the port notice of the winds and weather they will probably meet during the subsequent twenty-four hours. The Siccawei Observatory will be able to accomplish both these ends, provided it receives the co-operation of the various shipmasters resorting to the coast of China. It is recommended that every vessel should be provided with a register in which at stated intervals during the day the conditions of the barometer and thermometer, the direction and force of the wind, and the quantity of rain are accurately recorded. In addition to these the various lighthouse keepers and officers at Custom stations along the coast should kecp a similar register. The director of the observatory will have in these numerous observations a basis on which to work, and his investigations and the result will be made public as widely as possible.

Father Dechevrens then proceeds to describe what is already known of the meteorology of the China seas. Two kinds of storms prevail there, those from the north, which may be called the storms of winter, or the northern monsoon, and the typhoons, which are, properly speaking, storms of summer, or the southern monsoon. The first come from the interior of Asia and travel towards the North Pacific from west to east, while the second generally remain confined to the neighbourhood of the Philippines, Formosa, and the Gulf of Tonquin. In order to study these storms more effectually, the observatory should receive, twice daily, meteorological observations from Manila, Hongkong, Amoy, Tientsin, Nagasaki, and Vladivostock. By these means warnings can be rapidly conveyed to and from Shanghai of storms coming either from the north or south. The observatory at Siccawei, moreover, should be connected by telephone with the foreign concession in Shanghai, and Father Dechevrens offers the services of one of his observers for the Shanghai end of the line. The Director concludes his Report with the observation that the work will not be one of a day, for everytbing is yet to be done. "The meteorology of these countries must be commenced at its foundation."

The recommendations contained in this Report were all adopted by the Chamber of Commerce, the members taking on themselves all the financial and business management of the undertaking. The owners of vessels and the Chinese Customs were called upon to supply the instruments necessary for observing, which were those recommended by the Meteorological Office in London, and already in use in some British mail steamers. The agent of the Great Northern Telegraph Company has promised to transmit the daily reports free of charge, and it is anticipated that the Chinese authorities and the local underwriters will contribute the funds necessary for carrying out the project.

Taken in conjunction with the establishment of a complete observatory in Hongkong, for which, as we have already mentioned, the Colonial Government has liberally provided, the scheme above described is one of much scientific and practical importance. Although several observatories are already in existence at various parts of the China seas, no combined attempt has been made to study systematically the meteorology of these regions. The project which has now been adopted by the Shanghai Chamber of Commerce helps to bring to a focus a number of observations which, taken singly, are of small value, but when collected and examined by competent scientific men, cannot fail to produce beneficial results

\section{THE AURORA ${ }^{1}$}

$$
\text { II. }
$$

$A S$ we have said, it was not uncommon at the Vega's winter quarters to see two or more auroral-arcs, one of which was generally the "common arc." The second was nearly parailel to it and separated from it by an unlighted space which was sometimes crossed by rays of light. It would be most important for a thorough knowledge of auroræ to know the true mutual position of the arcs; but here again simultaneous measurements at two distant places are necessary, and not having such, Nordenskjöld remarks that three suppositions may be made. First, that the two arcs have irregular positions with regard to one another; secondly, that they are superposed on one another, having their centres on the same axis perpendicular to the surface of the earth; and third, that their centres are on the same radius of the earth, and that they are situated in about the same plane. In all three cases the aspects of the arcs would be quite different. The observations at the Vega's wintering place prove that the last case is the rule, and that arcs irregularly situated with report to ore anotber, or crossing one another (which would correspond to the first and second supposition), are exceptions; and Nordenskjöld arrives at the conclusion that the auroræ-arcs which were seen from the Vega, were usually in about the same plane. It might be asked, however, if it were not more natural to suppose that both rings are at the same distance from the earth's surface, their centres being situated on the same radius of the earth? But on March 14 two parallel arcs appeared, and soon joined together into a broad belt, the interior edge of which was $5^{\circ}$, and the exterior one was $15^{\circ}$ above the horizon, both edges being quite concertric,

I A. E. Nordenskjöld, "Om ncrrskenen under Vegas öfvervintring vid, (The Scientific Work of the Vega Expedition, part r, pp. 40I-452.) Continued from p. 321 . 